\title{
EFEKTYWNE ZASTOSOWANIE WYMAGAŃ STANDARDU ISO 28000 W PRZEDSIĘBIORSTWACH TRANSPORTOWYCH
}

$W$ artykule omówiono przełożenie zasadności wdrażania $i$ stosowania usystematyzowanych standardów zarządzania $w$ branży logistycznej $w$ oparciu o standard ISO 28000. Zwrócono uwage, iż standard zarzadzania łańcuchem dostaw coraz częściej jest wdrażanych $w$ przedsiębiorstwach transportowych. Sformalizowane $i$ często certyfikowane standardy zarządzania poprawiaja efektywność zarządzania transportem, podnosza bezpieczeństwo oraz wzbudzaja zaufanie wśród kooperantów. Standard ISO 28000 dotyczy zarówno dużych międzynarodowych przewoźników jak i małych firm transportowych.

\section{WSTĘP}

Tematyka transportu jest jednym z kluczowych ogniw biznesu. W zasadzie nie ma działalności gospodarczej, gdzie nie występował by element transportu. Stąd też transport jest odrębną gałęzią gospodarczą, służącą innym branżom. Działania w obszarze transportu często wskazuja na masowe wdrażanie systemów ISO 9001 (systemów zarządzania jakością [1]), dla zapewnienia odpowiedniej jakości realizowanych usług. Jednak jest to niewystarczające, stąd też powstał standard zarządzania „łańcuchem dostaw”, którego wymagania właśnie opisane są w normie ISO 28001. Zdefiniowanie pojęcia „zarządzanie łańcuchem dostaw” nie jest proste. Podjał się tego m.in. T. Skojett-Larsen [2] określając to działanie jako zorganizowanie działanie wszystkich ogniw w ciagu dystrybucji towarów. Zatem standard ISO 28001 ma na celu zorganizowanie działań w obszarze logistyki i transportu. Dal wielu przedsiębiorców sektora transportowego efektywne wdrożenie systemu daje możliwości budowania większego zaufania klientów do przedsiębiorstwa transportowego oraz oszacowanie ryzyka i eliminację zagrożeń związanych z usługą transportową.

\section{BUDOWA STANDARDU ISO 28000}

Mówiąc o standardzie ISO 2800 należałoby wspomnieć o szeregu norm wspomagających systemowe zarządzania w łańcuchu dostaw. Podstawą do wdrażania jest norma ISO 28001:2007 [3] Systemy Zarządzania Bezpieczeństwem Łańcucha Dostaw- najlepsze praktyki realizacji zabezpieczania łańcucha dostaw, jego oceny i planowania. Wymagania i wytyczne oraz ISO 28000 [4] System Zarządzania Bezpieczeństwem Łańcucha Dostaw- wymagania Jest to norma zawierająca wszystkie wymagania jakie należy spełnić aby uzyskać certyfikat. Jednak norma, ta podobnie jak inne normy systemów zarządzania ISO, wspierana jest normami pomocniczymi. ISO 28004 [5] zawiera wytyczne niezbędne i pomocne do prawidłowego wdrożenia systemu zarządzania łańcuchem dostaw. Jej celem jest zwrócenie uwagi na zagrożenia przemytu czy terroryzmu i przeciwdziałanie im. Norma ISO 28003 [6] zawiera wymagania dla audytowania systemów - norma ma zapewnić bezstronność przeprowadzanych przez jednostki certyfikujące ocen skuteczności funkcjonowania systemów. Norma ISO 28004 [7] zawiera wytyczne do wrażania, lecz skupia się głównie na określeniu danych wejściowych i wyjściowych procesów w łańcuchu dostaw oraz określeniu skutecznych mierników dla tych procesów. Oczywiście w zależności od gałęzi przemysłu powyższe normy wpierane są szeregiem norm branżowych bezpieczeństwo $w$ transporcie elektroniki, $w$ transporcie spożywczym, bezpieczeństwo kolejowe, lotnicze itp. Jak twierdzi A.Grzelakowski [8] proces zapewnienia ciagłości łańcucha jest rozległy i działający na szerokim obrzeże [9]. Niezależnie od ilości i rodzaju norm, system zarządzania łańcuchem dostaw jest istotny dla przedsiębiorstw transportowych. Jego zasady i wymagania sa ściśle określone i wymagane jednoznacznie przy certyfikacji.

\section{WYMAGANIA STANDARDU ISO 28000}

Zarówno sektor małych i średnich firm przewoźniczych dajacych usługę outsourcingu [9] jak i duże koncerny transportowo logistyczne są ogniwami w całym łańcuchu dostaw. Aby łańcuch ten miał ,jednolite oczka” przewoźnicy powinni spełniać te same wymagania - wymagania normy ISO 28001.

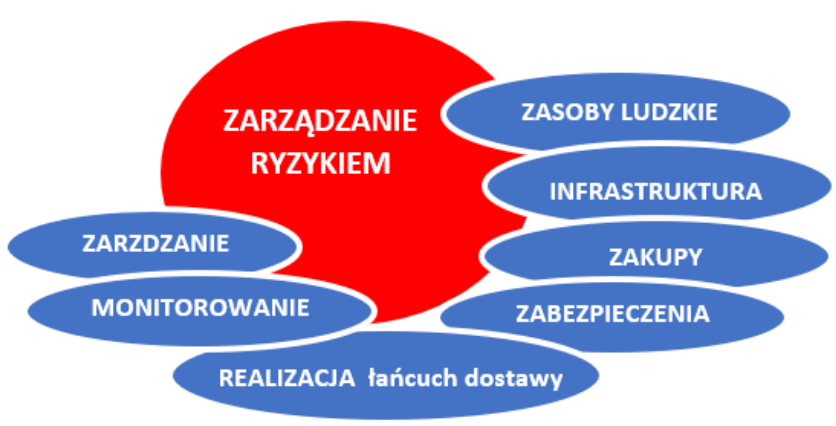

Rys. 1. Przesłania normy ISO 28001.

Podstawowe wymagania norm / systemu zarządzania w temacie w temacie łańcucha dostaw definiuje ISO 28001. Niezależnie od wyżej przytaczanych norm wspierających wymagania te są jasno określone w następujący sposób:

- ustalenie metod, narzędzi i procedur identyfikacji potencjalnych zagrożeń i rzeczywistych zagrożeń w łańcuchy dostaw,

- ustalenie kryteriów i mechanizmów oceny zagrożeń w odniesieniu do skali zagrożenia mogącego wystapić w trakcie transportu - ustalenie możliwości opanowania skutków,

- zbudowanie systemu prewencji,

- wyznaczenie jednoznacznych zasad reagowania na incydenty w łańcuchu dostaw, 
- ustalenie procedur działań naprawczych, korygujących i prewencyjnych,

- wyznaczenie i wdrożenie mechanizmów ponownej oceny zagrożeń po wystapieniu incydentu w transporcie,

- zbudowanie i wprowadzenie zasad sprawnego przepływu informacji,

- określenie uprawnień, kompetencji i odpowiedzialności oraz dostępu do informacji w całym łańcuchu dostaw,

- określenie zasad prowadzenia zapisów i dokumentowania zdarzeń oraz funkcjonowania systemu,

- nadzorowanie środowiska pracy i infrastruktury,

- ocena dostawców / podwykonawców w łańcuchu oraz kontrola jakości i bezpieczeństwa dostaw,

- wprowadzenie działań nadzorowania niezgodności i działań doskonalących,

- systematyczne przeprowadzanie audytów wewnętrznych i zewnętrznych zarówno w obszarze działalności jak i systemu,

- przeprowadzanie przeglądów zarządzania z uwzględnieniem doboru monitorowania i narzędzi raportowania.

Warto zwrócić uwagę, iż norma w wielu miejscach podkreśla istotę analizowania zagrożeń i podejmowania działań prewencyjnych. Powyższe wymagania są zbiorem dobrych praktyk, jakie powinny być stosowane w branży transportowej dla zapewnienia ciagłości działania w całym łańcuchu dostaw.

\section{EFEKTY WDROŻENIA STANDARDU ISO 28000 W MAŁYCH FIRMACH TRANSPORTOWYCH}

Coraz częściej małe firmy przewozowe przymierzaja się do wdrażania i certyfikowania systemu ISO 28000. Niejednokrotnie mali przedsiębiorcy chcąc być zakwalifikowanym dostawcą / podwykonawcą dużego przewoźnika zobligowani są do wdrożenia tego systemu. Uzyskują certyfikat znacząco zwiększają swoją przewagę rynkową oraz uzyskują zaufanie partnerów. Dla odbiorców branży kolejowej certyfikaty i wdrożone systemy są pewnego rodzaju gwarancją funkcjonowania w łańcuchu dostaw.

Czy dla małych przewoźników rzeczywiście system przekłada się na wzrost bezpieczeństwa przewożonych towarów? Co zmienia wdrożenie systemu zarządzania ISO 27000 w niewielkich przedsiębiorstwach transportowych?

Na podstawie przeprowadzonych badań własnych, na celowo wybranej próbie małych przewoźników zidentyfikowane zostały czynniki / obszary, które pośrednio mają wpływ na finalne bezpieczeństwo w całym łańcuchu dostaw. Poniżej przedstawiono efekty wdrożenia ISO 27000 - skuteczność w poszczególnych obszarach:

Obszar I - identyfikacja i stosowanie wymagań prawnych:

Po wdrożeniu systemu funkcjonowania w łańcuchu dostaw odnotowano znaczący wzrost ilości zidentyfikowanych wymagań prawnych. Ponadto w znaczący sposób wzrosło zastosowanie czyli spełnianie wymagań prawnych, zwłaszcza w obszarach do tej pory nie zidentyfikowanych. W efekcie przyniosło to znaczacy wzrost świadomości konsekwencji nie stosowania wymagań prawnych.

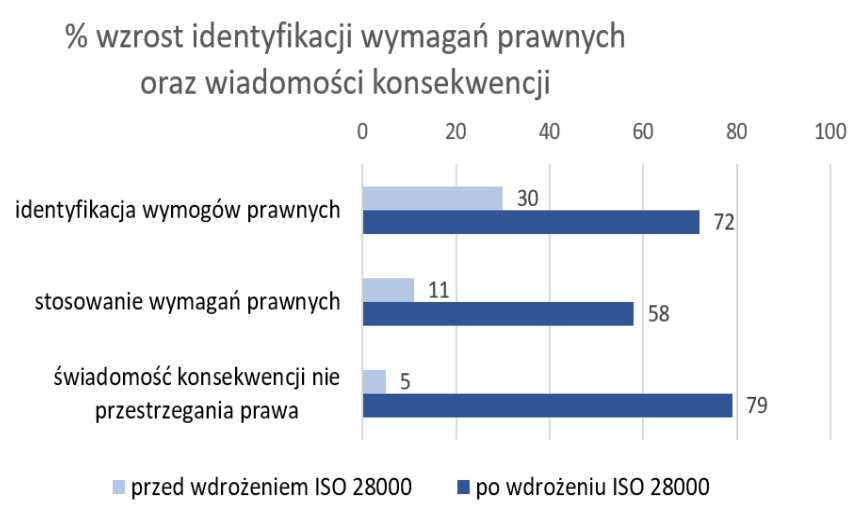

Rys. 2. Wzrost identyfikacji wymagań prawnych i wzrost świadomości ich stosowania w stosunku do sytuacji przed i po wdrożeniu systemu zarządzania w łańcuchu dostaw.

Obszar II - Identyfikacja zagrożeń i ocena ryzyka

Po wdrożeniu systemu zarządzania ISO 28000 organizacje zaczęły bardziej skupiać się na zagrożeniach ich otaczających. Do tej pory nie prowadzone sformalizowane zapisy z oceny ryzyka, zostały sformalizowane i przynoszą konkretne informacje przewoźnikom.

\% wzrost identyfikacji ryzyk i ich dokumentowanie

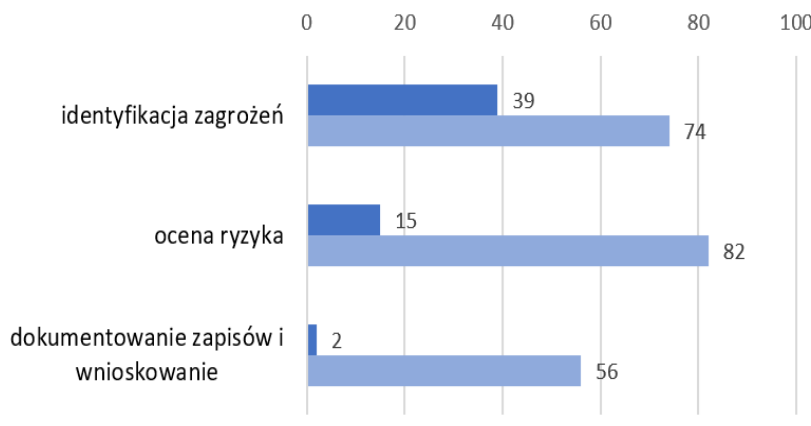

" przed wdrożeniem ISO 28000 " po wdrożeniu ISO 28000

Rys. 3. Wzrost znaczenia identyfikacji ryzyka i wagi dokumentowania wyników oceny ryzyka.

Obszar III - dokumentowanie działań

W przedsiębiorstwach transportowych, gdzie wdrażane były systemy zarządzania ISO 28000 procesy podstawowe transportowe i logistyczne zazwyczaj są dość dobrze dokumentowane. Dokumentowanie działań prowadzone jest zarówno w formie papierowej (zwłaszcza w zakresie wymagań prawnych) jak i elektronicznej np. przy wykorzystaniu lokalizacji GSM. Bardzo dobrze prowadzone są zapisy z wyników operacji np. protokoły przekazania towaru. Ustalenie zasad dokumentowanie nieznacznie zmieniło samo dokumentowanie działań, natomiast znacząco zmieniło podejście do dokumentowania działań systemowych. W sposób usystematyzowany podjęto działania archiwizowania i udostępniania dokumentów / informacji. Znacząco wzrosła świadomość ryzyka utraty informacji. 
$\%$ wzrost dokumentowania

działań operacyjnych i systemowych

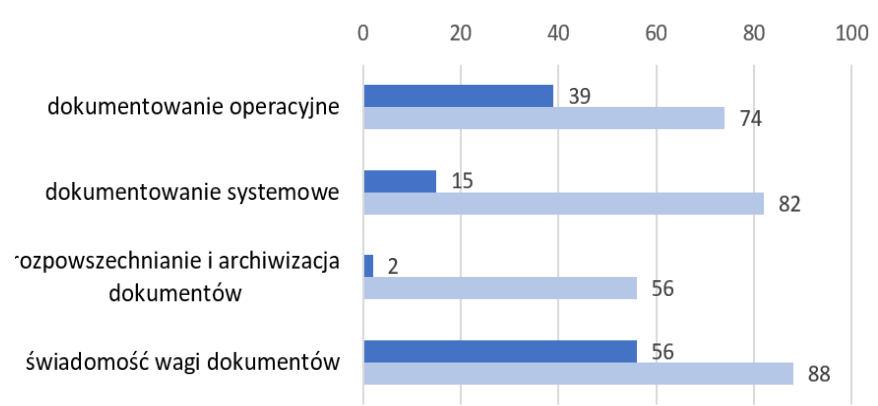

a przed wdrożeniem ISO 28000 po wdrożeniu ISO 28000

Rys. 4. Dokumentowanie działań operacyjnych i systemowych udostępnianie, archiwizacja dokumentów.

Obszar IV - Świadomość i odpowiedzialność

Po wdrożeniu systemu zarządzania ISO 28000 zauważyć można znacząca poprawę w określeniu odpowiedzialności, uprawnień, kompetencji w obszarze łańcucha dostaw, a zwłaszcza w obszarze decyzyjności. Nastapił wzrost sformalizowania tych działań, co znalazło odzwierciedlenie w umowach z pracownikami i podwykonawcami.

\section{\% sformalizowania w obszarze zakresów obowiązków} po wdrożeniu systemu zarządzania oraz wzrost świadomości pracowników.

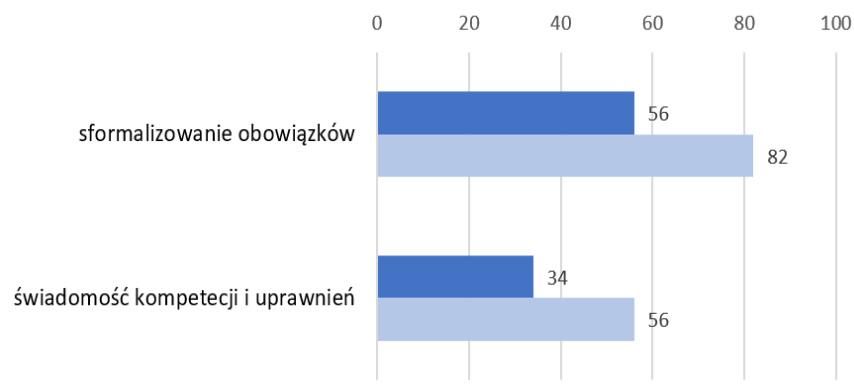

— przed wdrożeniem ISO 28000 po wdrożeniu ISO 28000

Rys. 5. Wzrost stopnia określenia i sformalizowania w obszarze zakresów obowiązków po wdrożeniu systemu zarządzania.

Obszar V- Zarządzanie infrastruktura

W ujęciu systemowym łańcucha dostaw zasoby występuja w dwóch obszarach - zasoby informatyczne oraz zasoby w postaci środków transportu. Systemowe dbanie o sprawność infrastruktury zapewnia ciagłość działania i obniża koszty potencjalnych awarii, przestoi oraz dostępu do danych lub ich utraty. Wdrożenie ISO 28000 sprawiło, że przedsiębiorstwa logistyczne i transportowe zaczęły planować przeglądy infrastruktury doprowadzając do przewidywalności niedostępności infrastruktury.

\section{\% planowania i przewidywalności dostępności} zasobów

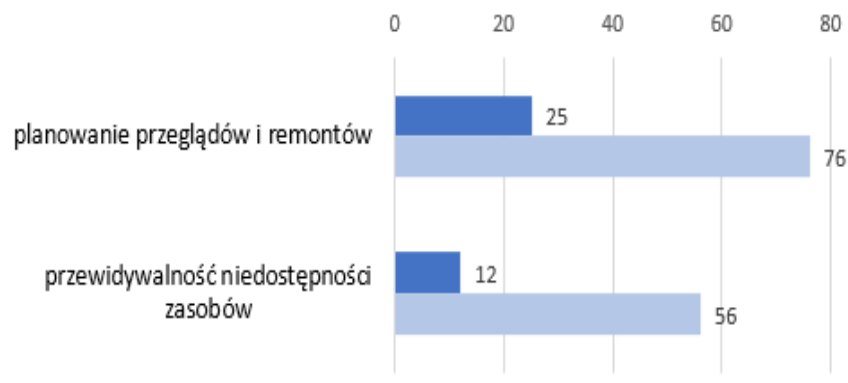

| przed wdrożeniem ISO 28000 || po wdrożeniu ISO 28000

Rys. 6. Przy systemowym nadzorowaniu infrastruktury wzrasta przewidywalność niedostępności zasobów.

Obszar VI - identyfikacji błędów (niezgodności)

Wprowadzenie systemów zarządzania łańcuchem dostaw w małych firmach transportowych nie wpłynęło na zmianę ilości wykrywalności błędów, niezgodności. Poziom zaistniałych niezgodności jest mały w tych przedsiębiorstwach, a zmiany w świadomości i zmiany w organizacji zarządzania nie miły wpływu ilość i rejestrowalność niezgodności.

\section{\% zmiana ilości zarejestrowanych niezgodności}

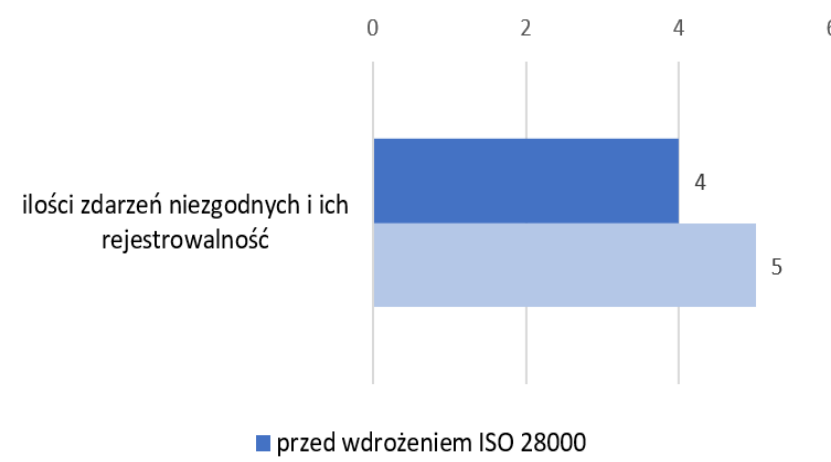

Rys.7. Brak zmian w ilości identyfikowalnych zmian.

Obszar VII - Audytowanie systemów

Wprowadzenie narzędzi badania skuteczności funkcjonowania systemu zarządzania stosowane również $w$ innych systemach zarządzania. Mechanizm audytowania jest również wymagany $w$ obszarze łańcucha dostaw. W badanych przedsiębiorstwach przeprowadzane są na bieżąco audyty wewnętrzne jak i audyty zewnętrze - prowadzone przez jednostki certyfikujące i prowadzone przez klientów. W badanych firmach audyty nie stały się narzędziem kontroli lecz stymulatorem do stałego doskonalenia struktur i mechanizmów zarządzania organizacja. Przedstawiciele firm transportowych zwracają uwage, iż opinia audytorów z poza ich organizacji często jest obiektywna i trafna. Opnie te często wpływają na poprawę jakości oferowanych usług. 


\section{\% skuteczność audtyów}

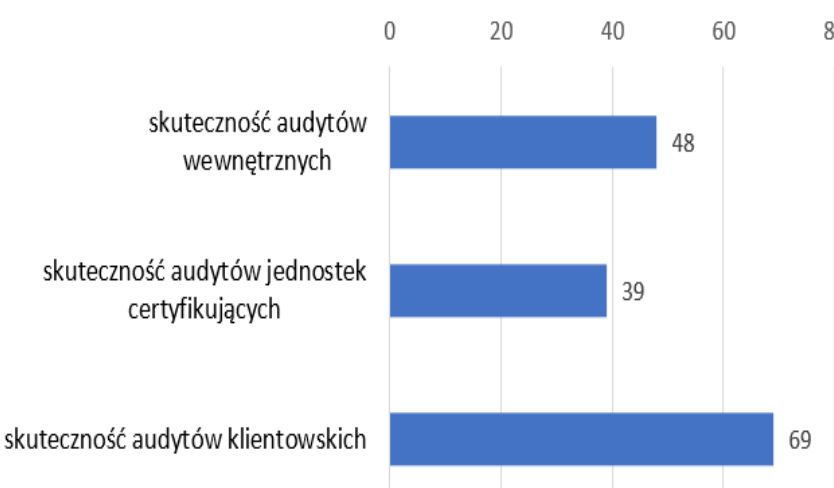

- skuteczność audytów

Rys. 8. W drugim roku funkcjonowania systemu odnotowano wzrost przydatności audytów dla funkcjonowania systemu.

Badane przedsiębiorstwa jednoznacznie twierdzą że wdrożenie systemu zarządzania łańcuchem dostaw pozytywnie wpłynęło na funkcjonowanie ich organizacji. Spełnienie wymagań porządkuje funkcjonowanie przedsiębiorstwa oraz umacnia w pozycję w łańcuchu dostaw. Firmy transportowe posiadajace certyfikat potwierdzający spełnienie wymagań normy ISO 28001 staja się wiarygodnym partnerem. Przyznać jednak należy, że część firm transportowych poniekąd została przymuszona biznesowo do wdrożenia tego systemu, a część potraktowała system jako szansę zaistnienia na rynku transportowym.

Wracając zatem do pytania czy wdrożenie systemu zarządzania $w$ łańcuchu dostaw daje wymierne efekty przedsiębiorstwu odpowiedzieć należy, tak. W jednych przedsiębiorstwach więcej zostaje wdrożonych zmian i zabezpieczeń organizacyjnych w innych mniej. Nie miej jednak, wdrożenie systemu zarządzania wpływa bardzo pozytywnie na samo funkcjonowanie przedsiębiorstwa. Znajomość przepisów prawa pozwala na zwiększenie bezpieczeństwa. Zwiększenie świadomość i odpowiedzialności (również karnej) sprawia, że zagrożenia i ryzyka są identyfikowane i analizowane. Realizowane zlecenia sa przemyślane, lepiej nadzorowane co w konsekwencji podnosi bezpieczeństwo. Systemowe eliminowanie błędów, weryfikacje podwykonawców, żądania ubezpieczeń, certyfikatów, zwiększa gwarancję jakości realizowanych usług. Poszczególne etapy kontroli, weryfikacji, przeglądów, monitorowania, audytów wewnętrznych oraz zewnętrznych są działaniami ukierunkowanymi na eliminację błędów oraz wprowadzanie mechanizmów zapobiegania błędom na przyszłość, co w efekcie daje gwarancję bezpieczeństwa w całym łańcuchu dostaw. Pamiętać jednak należy, że nawet najlepsze systemy zarządzania mobilizuja do eliminowania zagrożeń lecz nie gwarantuja, że zagrożenia nie wystapią.

\section{PODSUMOWANIE}

Od wielu lat branża transportowa rządzi się swoimi prawami. Jednak przy zmieniającym się rynku, gdzie oprócz dużych koncernów przewoźniczych pojawiają się także małe i mikro przedsiębiorstwa świadczące usługi transportowe, które również mają wpływ na bezpieczeństwo w poszczególnych ogniwach łańcucha dostaw. Stale przybywa przedsiębiorców polskich i zagranicznych, specjalizujacych się branży transportowej, stąd też pojawiaja się regulacje prawne, rozporządzenia unijne oraz standardy czy normy branżowe mające na celu zunifikowanie działań w tej dziedzinie. Wydaje się, że na dzień dzisiejszy, mobilizowanie przedsiębiorstw różnych wielkości do wdrażania ujednoliconych zasad, ujednoliconych systemów zarządzania, w tym systemów zarządzania w łańcuchu dostaw, jest najskuteczniejszą metodą w kierunku budowy ujednoliconego rynku transportowego będącego podstawą bezpieczeństwa w tym obszarze.

\section{BIBLIOGRAFIA}

1. PN-EN ISO 9001:2015 „System zarządzania jakością - Wymagania"

2. Skojett-Larsen T. Supply chain management: a new challenge for researchers and managers in logistics, W "International Journal of Logistics Management" cz.10 nr 2, s.40-42

3. ISO 28001:2007 Security management systems for the supply chain. Best practices for implementing supply chain security, assessments and plans. Requirements and guidance, International Organization for Standarization, 2007.

4. ISO/PAS 28000:2005 Wymagania dla systemu zarządzania bezpieczeństwem łańcucha dostaw - Wymagania

5. ISO/PAS 28004:2006 - Systemy zarządzania bezpieczeństwem dla łańcucha dostaw - wytyczne dla wdrożenia ISO/PAS 28000

6. ISO/PAS 28003 - Wymagania dla auditowania i certyfikacji systemów zarządzania bezpieczeństwem łańcucha dostaw.

7. ISO/PAS 28004:2006 Wytyczne do wdrożenia Systemu Zarzadzania Bezpieczeństwem Łańcucha Dostaw.

8. Grzelakowski A. „Uwarunkowania i bariery transportowe funkcjonowania i rozwoju globalnych łańcuchów dostaw" w Zeszyty Naukowe / Szkoła Główna Handlowa. Kolegium Gospodarki Światowej nr 31, 2011, s.141-160

9. Kisperska-Moroń, Danuta; Klosa, Edyta; Świerczek, Artur; Piniecki, Ryszard. Funkcjonowanie małych i średnich firm produkcyjnych w łańcuchu dostaw. Red. . Katowice: Wydawnictwo Uniwersytetu Ekonomicznego w Katowicach, 2010, s. 194-196

Autor:

dr inż. Natalia Jagodzińska - BTCH Systemy Zarządzania Gdańsk, Audytor Wiodący Systemów Zarządzania, e-mail: natalia.jagodzinska@outlook.com

JEL: R42 DOI: 10.24136/atest.2018.251

Data zgłoszenia: 2018.05.29 Data akceptacji: 2018.06.15 